\title{
STRATEGI SMP MUHAMMADIYAH BOARDING SCHOOL YOGYAKARTA DALAM PEMBIASAAN KARAKTER KEWARGANEGARAAN PADA PESERTA DIDIK
}

\author{
Lisa Retnasari ${ }^{1,}$ Suharno ${ }^{2}$ \\ Pendidikan Guru Sekolah Dasar Universitas Ahmad Dahlan ${ }^{1}$ \\ Pendidikan Pancasila dan Kewarganegaraan Universitas Negeri Yogyakarta ${ }^{2}$ \\ Email : Lisa.retasari@ pgsd.uad.ac.id ${ }^{1}$
}

Naskah diterima: 13/12/2017 revisi: 28/03/2018 disetujui: 30/04/2018

\begin{abstract}
Abstrak
Penelitian ini bertujuan mengungkapkan proses, strategi, faktor pendukung dan penghambat dalam pembiasaan karakter kewarganegaraan di SMP Muhammadiyah Boarding Yogyakarta. Jenis penelitian ini adalah penelitian deskriptif dengan pendekatan kualitatif. Subjek penelitian menggunakan purposive yaitu ketua yayasan, kepala sekolah, guru mata pelajaran, pembina asrama, dan pembina ekstrakurikuler di SMP MBS Yogyakarta. Data dikumpulkan dengan observasi, dokumentasi dan wawancara. Hasil penelitian menunjukan bahwa proses pembiasaan karakter kewarganegaraan dilakukan secara menyeluruh melalui proses kegiatan pembelajaran, kultur sekolah, kegiatan ekstrakurikuler, dan kegiatan bermasyarakat; strategi pembiasaan karakter kewarganegaraan dilaksanakan melalui pemberian nasihat, pembiasaan akhlak baik, adanya penghargaan dan sanksi, serta keteladanan guru (ustaz/ustazah); dan faktor pendukung pembiasaan karakter kewarganegaran terdiri atas faktor internal dan eksternal. Faktor internal berupa tata tertib dan kultur sekolah, dukungan dan kerja sama yang baik antarseluruh warga sekolah, dan dukungan orang tua, serta faktor eksternal berupa dukungan dan kerja sama antar pihak sekolah dan masyarakat. Faktor penghambat terdiri atas minimnya sarana dan prasarana, jumlah proporsi yang tidak seimbang antara jumlah pembina dan peserta didik, pembiayaan, dan karakter peserta didik dengan latar belakang keluarga yang berbeda.
\end{abstract}

Kata kunci: boarding school, karakter kewarganegaraan, strategi pembiasaan

\section{THE STRATEGY OF SMP MUHAMMADIYAH BOARDING SCHOOL YOGYAKARTA TO INCULCATE THE CIVICS DISPOSITION IN THE STUDENTS}

\begin{abstract}
This research aims at revealing the processes, strategies, factor endowments and a barrier in conditioning citizenship on character SMP Muhammadiyah Yogyakarta Boarding. Type of this research is descriptive research with qualitative approach. The subject of research using the purposive namely Foundation, principals, teachers, subjects, and pembina pembina extracurricular MBS in junior high. Data collected by observation, documentation and interviews.. The results of the research showed that process of civics character habituation at SMP MBS Yogyakarta has been done holistically through teaching and learning activities, school culture, extracurricular activities, and social activities; the strategy of civics character habituation at SMP MBS Yogyakarta is held by counseling, accustoming good morals and attitude, giving reward and punishment, and providing good examples or models of the teachers; the supporting factor and the constraints of civics disposition habituation at SMP MBS Yogyakarta have external and internal characteristics. The internal factors were discipline and school culture, support and good cooperation between all people in schools, and support from parents. The as external factors were cooperation with the school community. The inhibiting factors consisted of lack of infrastructure, the number of unbalanced proportion between the number of supervisors and learners, financing and different backgrounds of learners.
\end{abstract}

Copyright (C) 2017, Citizenship Jurnal Pancasila dan Kewarganegaraan

Avaliable online at : http://e-journal.unipms.ac.id/index.php/citizenship

Print ISSN: 2302-433X Online ISSN : 2579-5740 


\section{PENDAHULUAN}

Derasnya arus global tanpa disertai filter dari masyarakat Indonesia, mengakibatkan rakyat mudah terbawa arus kebebasan dan indivudualisme, yang bedampak langsung terhadap menurunnya kualitas moral bangsa. Adanya penurunan kualitas moral bangsa saat ini, dicirikan dengan maraknya praktik Korupsi, Kolusi, dan Nepotisme (KKN), terjadinya konflik (etnis, agama, politis, remaja), meningkatnya kriminalitas, menurunnya etos kerja, dan sebagainya (Ratna Megawangi, 2004: 14). Lebih dari pada itu, krisis moral ini pun melanda generasi muda di persekolahan.

Sekolah yang notabenya sebagai jalur pendidikan formal sampai sekarang masih dipercaya untuk mewujudkan tujuan pendidikan nasional. Namun seiring berjalannya waktu, menurut William Kilpatrick (Lickona, 2013: 3) banyak persoalan mendasar yang dihadapi oleh sekolah yaitu persoalan moral. Persoalanpersoalan yang lain bersumber dari persoalan ini. Bahkan reformasi akademis bergantung pada bagaimana seseorang mengedepankan karakter. Akan tetapi sekolah yang menjadi harapan dalam penanaman nilai-nilai karakter ternyata belum mampu menjalankan secara optimal. Sekolah yang menjadi harapan dalam penanaman nilai-nilai ternyata belum mampu secara optimal melakukan itu. Penelitian yang telah dilakukan oleh Darmiyati Zuchdi, dkk (2006: 7) menemukan bahwa konteks institusional sekolah masih belum secaraoptimal mendukung pelaksanaan pendidikan nilai/karakter, sekolah belum banyak menggunakan fasilitas nilai yang sesuai untuk melatih kemampuan membuat keputusan, serta iklim pendidikan karakter di sekolah secara umum masih tergolong sedang (artinya belum kondusif bagi pendidikan karakter).

Pemikiran tersebut sejalan dengan pendapat Doni Purnomo (2012: 1) yang mengungkapkan bahwa sejauh ini pendidikan karakter hanya sebatas konsep dan baru menyentuh tingkatan pengenalan norma atau nilai-nilai dan belum pada tingkat internalisasi dan tindakan nyata dalam kehidupan sehari-hari. Suatu gejala yang umum bahwa konteks tujuan pendidikan lebih kearah meraih kecerdasan dari pada pembiasaan karakter baik.
Yahya Khan (2010: 1) mengungkapkan bahwa pendidikan karakter mengajarkan kebiasaan cara berpikir dan berperilaku yang membantu individu untuk hidup dan bekerjasama sebagai keluarga, masyarakat bernegara dan membantu mereka membuat keputusan yang dapat dipertanggungjawabkan.

$$
\text { Ratna Megawangi (2007: 229) }
$$

menyatakan menjadi orang yang berkarakter baik adalah bukan karena dilahirkan (nature), tetapi tergantung bagaimana dia dididik (nurture). Fuad Hasan (Abdul Majid, 2011: 4) pendidikan itu bermuara pada pengalihan nilainilai budaya dan norma-norma sosial. Menurut Akhmad Muhaimin (2011: 27) pendidikan karakter adalah pendidikan budi pekerti plus yang melibatkan aspek pengetahuan (cognitive), perasaan (feeling), dan tindakan (action). Tanpa ketiga aspek ini, pendidikan karakter tidak akan efektif, jadi yang diperlukan dalam pendidikan karakter tidak cukup dengan pengetahuan lantas melakukan tindakan yang sesuai dengan pengetahuan saja. Hal ini karena pendidikan karakter terkait erat dengan nilai dan norma. Oleh karena itu, harus juga melibatkan perasaan.

Melihat potret tersebut pembiasaan karakter yang optimal tentunya tidak hanya ditangani oleh salah satu pihak, akan tetapi harus dilaksanakan secara menyeluruh oleh seluruh kalangan, dimulai pada lingkungan keluarga, masyarakat, sekolah serta pemerintah. Seperti yang diungkapkan oleh Kardiman (2008: 165) yaitu pembangunan karakter bangsa tidak saja menjadi tanggung jawab dunia persekolahan tetapi juga menjadi tanggung jawab situs-situs kewarganegaraan di luar persekolahan. Hal ini menegaskan bahwa PKn yang mengandung muatan nilai karakter, tidak hanya menjadi mata pelajaran di sekolah saja, tetapi menjadi pendidikan kewarganegaraan di lingkungan masyarakat.

Pendidikan kewarganegaraan merupakan istilah generik yang mencakup pengalaman belajar di sekolah dan di luar sekolah, seperti yang terjadi di lingkungan keluarga, dalam organisasi keagamaan, dalam organisasi kemasyarakatan dan media. PKn dalam lingkungan masyarakat menjadi wahana dalam pembentukan karakter yaitu memberi kontribusi pendidikan ditujukan untuk mencapai terbentuknya warga negara yang diinginkan oleh bangsa Indonesia yaitu warga negara yang 
memiliki karakter yang sesuai dengan nilai-nilai Pancasila. (Cogan, 1999: 4).

Boarding school merupakan lembaga pendidikan yang memadukan sistem pondok pesantren dan sistem pendidikan nasional dengan model pembinaan yang sarat akan pendidikan nilai, baik nilai agama maupun nilainilai luhur bangsa. Boarding school menjadi sebuah lembaga yang sangat efektif dalam pengembangan pendidikan karakter (akhlak) peserta didik. Seperti ungkapan Maksudin (2013: 25) bahwa sistem boarding school relevan dan cocok sebagai wahana pendidikan nilai-nilai moral bagi peserta didik.

Salah satu sekolah yang sudah menerapkan sistem boarding school di Yogyakrata yaitu Muhammadiyah Boarding School Yogyakarta atau yang lebih dikenal dengan MBS Yogyakarta. Pondok Pesantren Modern Muhammadiyah Boarding School (MBS) Yogyakarta merupakan salah satu yayasan pendidikan Islam berbasis Muhammadiyah yang mengembangkan pendidikannya dengan sistem boarding school dan mengunggulkan keseimbangan antara kurikulum umum dengan kurikulum pesantren (kemuhammadiyahan)

Berdasarkan dokumen resmi MBS

Yogyakarta komitmen yang kuat dalam pembangunan akhlak dibuktikan dengan adanya visi yakni "Terbentuknya Lembaga Pendidikan Pesantren yang Berkualitas dalam Menyiapkan Kader Muhammadiyah Berdasarkan Alquran dan As-Sunnah".

Hasil wawancara dengan Bapak Odjie Samroji selaku sekertaris di Muhammadiyah Boarding School melalui wawancara informal dengan peneliti. Bapak Odjie Samroji menegaskan bahwa barometer sebuah sekolah adalah ketika berhasil membentuk karakter anak dengan visi dan misi sekolah mapun pendidikan Indonesia.

Muhammadiyah Boarding School itu sendiri merupakan sekolah berbasis pesantren modern yang tidak hanya menekankan pembelajaran pada satu nilai saja, namun lebih beragam. Mulai dari nilai agama, sains, bahasa dan sosial melalui kegiatan yang dilakukan di SMP MBS Yogyakarta itu sendiri. Berdasarkan latar belakang tersebut, penulis tertarik untuk mengadakan penelitian mengenai strategi SMP Muhammadiyah Boarding School Yogyakarta dalam pembiasaan karakter kewarganegaraan pada peserta didik.

\section{METODE}

\section{Jenis Penelitian}

Jenis penelitian yang digunakan dalam penelitian ini deskriptif dengan pendekatan kualitatif. penelitian kualitatif adalah proses penelitian dengan menyelidiki masalah sosial. Peneliti membuat gambaran kompleks yang bersifat holistik, menganalisis kata-kata, melaporkan pandangan-pandangan para informan secara rinci, dan melakukan penelitian dalam situasi alamiah. Penelitian kualitatif sebagai bentuk penelitian yang mengharuskan menemukan suatu makna sebagai hasil dari eksplorasi terhadap data, kemudian data yang terkumpul dianalisis secara komprehensif dan mendalam dengan melibatkan informan atau partisipan sebagai sumber informasi (Creswell, 2013: 4)

\section{Waktu dan Tempat Penelitian}

Penelitian ini akan dilaksanakan di SMP Muhammadiyah Boarding School Yogyakarta yang terletak di desa Bokoharjo kecamatan Prambanan. Di SMP MBS Yogyakarta sangat menjunjung tinggi nilai kejujuran hal ini diwujudkan dengan tidak adanya sistem pengatrolan nilai dalam ujian. Kemudian pemilihan pada jenjang SMP, dikarenakan pada usia tersebut merupakan masa peralihan psikologis ke arah kematangan. Di masa remaja ini sering melakukan perilaku antisosial yang sering dikenal juvenile delinguice yaitu tindakan pelanggaran/kejahatan yang dilakukan remaja dan mnjurus pelanggaran hukum (Rita, 2008: 150). Oleh karena itu, perlu strategi pembiasaan pendidikan karakter pada peserta didik. Penelitian diawalai dengan kegiatan observasi pada bulan Agustus-September 2015.

\section{Target/Subjek Penelitian}

Subjek penelitian terdiri atas ketua yayasan, kepala sekolah, guru mata pelajaran, pembina asrama, dan pembina ekstrakurikuler di SMP Muhammadiyah Boarding School Yogyakarta.

\section{Prosedur}


Penelitian ini dilmulai dari menghimpun data dan melakukan pengamatan seksama, mencakup deskripsi dalam konteks yang mendetail disertai catatan-catatan yang lengkap mendukung data yang diperoleh. Dalam mengumpulkan data peneliti menggunakan metode observasi (pengamatan), wawancara, dan dokumentasi. Dari hasil pengumpulan data tersebut kemudian dilakukan analisa keabsahan data menggunakan trangulasi dan dilanjutkan pengambilan kesimpulan.

\section{Data, Intrumen, dan Teknik Pengumpulan Data}

Data pada penelitian ini merupakan data yang berkaitan dengan 1) proses pembiasaan karakter kewarganegaraan, 2) strategi SMP MBS Yogyakarta dalam pembiasaan karakter kewarganegaraan dan 3) faktor pendukung dan penghambat dalam pembiasaan karakter kewarganegaraan pada peserta didik. Data diambil mengunakan observasi, wawancara dan dokumentasi yang dipadukan dengan teknik proportional random sampling.

\section{Teknik Analisis Data}

Teknik analisis data yang digunakan dalam penelitian ini adalah teknik analisis data induktif, yang merupakan penarikan kesimpulan dari fakta-fakta yang khusus, untuk kemudian ditarik kesimpulan secara umum (generalisasi). Adapun langkah-langkah analisis data dalam penelitian ini adalah reduksi data, kategorisasi dan unitisasi data, display data, dan pengambilan kesimpulan, sebagaimana dikemukakan oleh Miles dan Huberman (1984), mengemukakan bahwa aktivitas dalam analisis data, yaitu: data reduction, data display, and data conclusion drawing verification.

\section{HASIL DAN PEMBAHASAN}

\section{Proses Pembiasaan Karakter Kewarganegaraan Pada Peserta Didik}

Muhammadiyah Boarding School selalu mengedapkan nilai akhlak dibanding kognitif. Mereka akan merasa gagal mencentak generasi penerus apabila setiap harinya akhlaknya tidak semakin baik. MBS ingin menekankan karakter yang seimbang dalam diri peserta didik. MBS sangat menyadari bahwa menanamkan karakter pada peserta didik, hingga sampai pada proses pembiasaan adalah pekerjaan yang sulit dan membutuhkan waktu yang lama. Oleh sebab itu upaya pembiasaan karakter tidak berhenti pada jam pelajaran di kelas, tapi juga berlanjut hingga kegiatan di asrama dan kegiatan lainnya. Dengan kata lain MBS dalam pembiasaan karakter kewarganegaraan dikemas secara menyeluruh (holistic), sehingga mampu mengembangkan ketiga ranah domain dalam pendidikan karakter.

SMP Muhammadiyah Boarding School merupakan lembaga pendidikan yang memiliki kewajiban mengembangkan pendidikan karakter. Proses pembiasaan karakter di SMP Muhammadiyah Boarding School di kemas secara menyeluruh (holistic), dimaksudkan agar menyentuh tiga ranah domain pendidikan karakter. Sesuai yang diungkapkan oleh Lickona (1991: 45); Marzuki\&Feriandi (2016) bahwa pentingnya tiga komponen karakter yang baik (components of good character), yaitu terdiri dari moral knowing, moral feeling, dan moral action. Dalam konteks proses pembiasaan karakter di SMP Muhammadiyah Boarding School Yogyakarta, tahap moral knowing disampaikan dalam dimensi kelas (sekolah atau pondok) antara peserta didik dengan gurunya. Kemudian moral feeling melalui pengalaman langsung peserta didik dalam konteks sosial dan personalnya. Selanjutnya moral action diwujudkan melalui tindakan nyata untuk hidup mandiri, bertanggung jawab, displin, menghormati antar individu dan lain sebagainya. Pendidikan karakter seyogyanya tidak sekedar mengajarakan mana yang baik dan mana yang salah kepada anak, tetapi pendidikan karakter lebih dari itu pendidikan karakter menanamkan kebiasaan (habituation) tentang yang baik, sehingga terbiasa melakukan tindakan yang baik. Ukurannya adalah peserta didik melalukan perbuatan baik menurut aturan yang berlandaskan $\mathrm{Al}$ quran dan As sunah sesuai visi dari Muhammadiyah Boarding School.

Pemerintah melalui Kementrian Pendidikan Nasional telah mengembangkan Grand Design pendidikan karakter untuk setiap jalur, jenjang, dan jenis pendidikan. Grand Design ini dapat dijadikan sebagai rujukan konseptual dan operasional terkait dengan pengembangan, pelaksanaan, dan penilaian pendidikan karakter pada setiap jalur, jenjang, dan jenis pendidikan di Indonesia. Di mana secara mikro pengembangan karakter dibagi ke dalam empat pilar yakni, kegiatan belajar mengajar di kelas, 
dalam bentuk budaya satuan pendidikan, kegiatan ko-kulikuler dan atau ekstrakulikuler, serta kegiatan keseharian di rumah dan dalam masyarakat (Kemendiknas, 2010: 30). Konfigurasi karakter dalam konteks totalitas proses psikologis dan sosio-kultural dapat dikelompokkan dalam empat konsep dasar, yaitu olah hati, olah pikir, olah raga dan kinestetik, dan olah rasa dan karsa (Masnur Muslich, 2011: $85)$.

Begitu pula pada lingkungan boarding school sebagai salah satu jalur pendidikan formal yang memiliki kurikulum gabungan antara pondok dan umum, yang melaksanakan pembiasaan secara menyeluruh. SMP Muhammadiyah Boarding School Yogyakarta telah mengembangkan pembinaan dan pembiasaan karakter kewarganegaraan melalui empat proses yakni, pembelajaran, kultur sekolah, kegiatan ekstrakurikuler dan melalui kegiatan bermasyarakat.

\section{Proses Pembiasaan Karakter Kewarganegaraan Melalui KBM}

Pembiasaan karakter dilakukan melalui proses penyampaian mata pelajaran (transfer of knowladge). Pada proses belajar mengajar yang dilakukan oleh tiap-tiap guru memiliki strategi maupun pedoman tersendiri dalam menyampaikan materi kepada setiap peserta didik.

Pedoman ini berupa silabus dan Rencana Pelaksanaan Pembelajaran (RPP). Dalam penyusunan RPP berkarakter merupakan produk program pembelajaran jangka pendek, yang mencakup komponen program belajar dan proses pelaksanaan progam. Pada RPP harus jelas karakter dan kompetensi dasar yang dimiliki oleh peserta didik, apa yang harus dilakukan, apa yang harus dipelajari, bagaimana mempelajarinya, serta bagaimana guru mengetahui bahwa peserta didik memiliki karakter tertentu. Proses pendisiplinan dilakukan ketika masuk ke dalam kelas dengan cara memulai pembelajaran dengan berdoa atau membaca kitab suci $\mathrm{Al}$ quran.

Selain itu guru-guru di SMP Muhammadiyah Boarding School untuk menerapkan nilai-nilai karakter juga dilakukan melalui kontrak belajar. Misalnya dalam kontrak belajar peserta didik atau gurunya melakukan keterlambatan selama 15 menit tanpa alasan, maka keduanya tidak boleh mengikuti pelajaran. Hal ini melatih displin dan bertanggungjawab para peserta didik.

Pengembangan RPP berkarakter harus memperhatikan minat dan perhatian peserta didik serta disesuaikan dengan kompetensi yang akan dicapai. Pembiasaan karakter kewarganegaraan di dalam mata pelajaran dialakukan sejak menyusun RPP. RPP terintegrasi muatan nilai-nilai karakter yang akan diberikan pada peserta didik. Hal ini sesuai dengan konten Character Count Coalition, di mana dalam RPP terdapat nilai-nilai karakter seperti kepercayaan, hormat, tanggung jawab, keadilan, kepedulian, dan kewarganegaraan.

Keberhasilan penyampaian materi dalam proses belajar ditentukan oleh penguasaan materi dan kemampuan guru dalam mengajar, sehingga peserta didik mampu memahami apa yang disampaikan guru. Pada proses pembelajaran ada tiga tahapan kegiatan pokok yang harus diperhatikan oleh guru, yaitu pendahuluan, kegiatan pembelajaran inti dan penutup serta tidak terlepas dari penilaian dan tindak lanjut. Namun tidak semua guru melaksanakan ketiga tahapan tersebut. Pembelajaran di kelas umumnya menggunakan metode ceramah dan pembiasaan. Metode pembiasaan sebagai upaya untuk memudahkan pemahaman karakter pada peserta didik.

\section{Proses Pembiasaan Karakter Melalui Kultur Sekolah}

SMP Muhammdiyah Boarding School Yogyakarta memiliki kultur sekolah yang berbeda dengan sekolah SMP lainnya di Yogyakarta, seperti upacara setiap hari Sabtu dengan 3 bahasa (Bahasa Indonesia, Bahasa Inggris dan Bahasa Arab) secara berurutan/bergantian setiap Sabtu, apel pagi setiap hari 10 menit sebelum bel masuk, berdoa sebelum dan sesudah pelajaran, sholat berjamaah baik sholat fardhu maupun sholat sunat, sholat Dhuha, puasa setiap Senin dan Kamis, tadarus rutin, memberi dan menjawab salam, membuang sampah di tempat sampah, budaya antri, berpakaian rapi dan menutup aurat, datang tepat waktu, bersalaman dengan guru jika bertemu, berkata sopan dan lembut, membiasakan berbahasa Inggris dan Arab dalam percakapan sehari-hari. 
Salah satu kultur sekolah yang menjadi ciri khas dari MBS yaitu setiap pagi para peserta didik dengan guru-guru saling bersalaman (mengucapkan salam), ditambah dengan senyum dan sapa. Proses pembiasaan karakter melalui kultur sekolah banyak sekali guna membentuk peserta didik yang mandiri, bertanggungjawab, jujur dan disiplin.

Dalam proses membina kedisiplinan segenap warga sekolah datang lebih awal baik guru maupun peserta didik. Kemudian kewajiban shalat berjamaah diwajibkan tidak hanya untuk peserta didik, tetapi juga gurunya. Selain itu guru juga diwajibkan pulang setelah shalat ashar yakni 15.30 WIB. Sekolah akan memberikan sanksi kepada peserta didik dan guru apabila mereka tidak disiplin.

Sanksi yang diberikan kepada guru yang tidak disiplin berupa teguran dan catatan dari kepala sekolah, sedangkan peserta didik diberi sanksi sesuai yang tercantum dalam buku panduan santri. Berbagai kegiatan yang diselenggarakan oleh sekolah tersebut merupakan salah satu upaya yang dilakukan sekolah untuk menanamkan nilai-nilai karakter sesuai dengan visi dan misi sekolah, serta tujuan dan fungsi pendidikan karakter melalui kultur sekolah.

\section{Pembiasaan Karakter Kewarganegaraan Melalui Ekstrakurikuler}

Di SMP Muhammadiyah Boarding School memiliki banyak sekali ekstrakurikuler yang dapat diikuti para peserta didik di sana. Harapan dari kegiatan ekstrakurikuler ini, nantinya anak mempunyai kecerdasan sosial, moralitas, arif dan bijaksana dalam menghadapi dan memecahkan problem yang mereka hadapi.

Ekstrakurikuler wajib seperti hizbul wathan dilakukan pada hari rabu mulai pukul 15.0017.00 WIB. Untuk memulai dan mengakhiri kegiatan selalu diselenggarakan apel. Tujuan utama hizbul wathan adalah memperkokoh takwa, membentuk akhlak dan watak yang berdasarkan imam kepada Allah SWT. Dengan harapan anggota HW memiliki rasa tanggung jawab terhadap keluarga, bangsa, cinta lingkungan dan tanah air.

Nilai kemandirian sangat nampak pada kegiatan ekstrakurikuler HW ini dibuktikan dibentuknya dewan kerabat. Dewan kerabat terdiri dari anggota HW yang lolos seleksi. Dewan kerabat kerabat dibekali life skill, bidang kepanduan, bidang teknologi dan bidang kemiliteran. Terkait dengan pendidikan karakter , dewan kerabat sangat dipersiapkan dengan maksud untuk memupuk dan mebiasakan kemandirian.

Ekstrakurikuler wajib selanjutnya yaitu tapak suci. Tapak Suci merupakan kegiatan ekstrakurikuler beladiri di PPM MBS Yogyakarta. Perguruan Seni Bela diri Indonesia Tapak Suci Putera Muhammadiyah atau disingkat Tapak Suci, adalah sebuah aliran, perguruan, dan organisasi pencak silat yang merupakan anggota IPSI (Ikatan Pencak Silat Indonesia). Tapak Suci termasuk dalam 10 Perguruan Historis IPSI, yaitu perguruan yang menunjang tumbuh dan berkembangnya IPSI sebagai organisasi. Tapak Suci berasas Islam, bersumber pada Alquran dan As-Sunnah, berjiwa persaudaraan, berada di bawah naungan Persyarikatan Muhammadiyah sebagai organisasi otonom yang ke-11. Tapak Suci berdiri pada tanggal 10 Rabiul Awal $1383 \mathrm{H}$, atau bertepatan dengan tanggal 31 Juli 1963 di Kauman, Yogyakarta. Motto dari Tapak Suci adalah "Dengan Iman dan Akhlak saya menjadi kuat, tanpa Iman dan Akhlak saya menjadi lemah".

Peserta didik dalam kegiatan ekstrakuriler ini dilatih untuk mempunyai respon reflek dengan baik dalam memecahkan setiap masalah yang mereka hadapi, hal ini butuh latihan dan pembiasaan dalam pengawalan guru dan orang tua.

$\begin{array}{lll}\text { Proses Pembiasaan } & \text { Karakter } \\ \begin{array}{l}\text { Kewarganegaraan Melalui } \\ \text { Bermasyarakat } \\ \text { Proses }\end{array} & \text { Kegiatan } \\ & \text { pembiasaan } & \text { karakter }\end{array}$
kewarganegaraan dalam hal ini berkaitan dengan masyarakat. MBS menjadikan masyarakat sebagai guru, guna mengetahui kehidupan yang sesungguhnya. Adapun program unggulan untuk melatih peserta didik menjadi pribadi yang peka terhadap sosial yang ada di sekitar. Kegiatan unggulan tersebut adalah amal bakti santri atau lebih sering dikenal dengan ABAS.

Kegiatan ABAS santri (peserta didik) ditempatkan di desa-desa terpencil yang jauh dari akses kemudahan teknologi. Ada kriteria khusus lingkungan yang akan ditempati para peserta didik seperti rumah yang dindingnya masih dari bambu, lantai masih tanah, kemudian memasak masih menggunakan kayu bakar. 
Teknisnya mereka dibagi menjadi kelompok yang terdiri 5-7 santri percampuran antara senior dan junior dari SMP sampai SMA. Bertempat di satu kampung atau kecamatan selama 4-5 hari. Mereka akan belajar bagaimana bersosialisasi dan membantu orang tua asuhnya. Apabila mereka tinggal di rumah petani, harus membantu pekerjaan di sawah. Begitu pula dengan peserta didik yang hidup bersama pedagang makanan keliling atau peternak sapi. Selain wajib membantu orang tua asuhnya peserta didik juga dituntut untuk belajar lebih mandiri.

Tujuan utama dari ABAS yakni membangkitkan kepekaan sosial peserta didik, agar mereka mengetahui kehidupan sosial masyarakat yang sesungguhnya. Adapun kegiatan lain yang juga melatih nilai karakter yang diterapkan melalui kerjasama dengan masyarakat selain ABAS. Sikap keramahan dan kebermasyarakatan MBS bisa nampak dalam kegiatan sebagai berikut 1) Bakti sosial dan penyaluran dana pendidikan. Semarak bulan Muharram (tahun baru Hijriyah) dimanfaatkan MBS sebagai momen untuk melakukan tablihg akbar dan santunan sosial. Yang hadir dalam acara ini adalah warga sekitar MBS dan masyarakat umum. Tujuan diselenggarakannya acara ini antara lain untuk syiar Islam. MBS turun mengenalkan kembali kepada ummat bahwa Islam mempunyai penanggalan tersendiri, yaitu penanggalan Hijriyah, yang dewasa ini mulai terlupakan, 2) Penyaluran zakat fithrah. Memasuki akhir bulan Ramadhan, MBS melakukan penggalangan dana zakat Fithrah dari semua santri MBS, baik putra maupun putri. Kemudian zakat yang terkumpul akan dibagikan kepada warga yang berhak (mustahiq) dengan sistem kupon. Selain sebagai syiar Islam dan tuntunan syariat, ternyata program ini juga mampu mendekatkan MBS dengan warga sekitar dalam suasana buka bersama dan silaturrahim, 3) Penyembelihan dan penyaluran hewan qurban. Pada momen hari raya Idul Adha, MBS berperan aktif dalam penggalangan dana dari shohibul Qurban, untuk melaksanakan penyembelihan hewan qurban di lingkungan MBS. Shohibul qurban yang menyalurkan kurabannya di MBS antara lain; para asatidz dan ustadzat serta karyawan MBS, santri dan santri wati MBS beserta wali-walinya. Untuk selanjutnya, hewan kurban yang terkumpul akan disalurkan kepada warga, baik dalam bentuk daging maupun hewan kurban hidup, 4) Penyelenggaraan khitanan massal. Inilah acara yang menjadi salah satu media dakwah agar keberadaan MBS bisa menjadi manfaat ditengah masyarakat. Khitanan masal dilakukan dengan mengundang para anak-anak yatim ataupun dhuafa dilingkungan Prambanan dan sekitarnya. Bekerjasama dengan PKU Muhammadiyah dilaksanakan bersamaan dengan perayaan Tahun Baru Hijriyah di bulan Muharam dan 5) Beapeserta didik Pendidikan untuk warga kurang mampu dan anak yatim. Kegiatan sosial yang dilakukan MBS Yogyakarta kepada para keluarga kurang mampu berupa santunan beapeserta didik pendidikan untuk anak-anak sekolah disekitar lingkungan Pesantren.

Adanya kegiatan tesebut diharapkan mampu mengantarkan peserta didik memiliki kompetensi dan mampu bersaing dalam bidang akademik maupun non akademik.

\section{Strategi Pembiasaan Karakter Kewarganegaraan pada Peserta Didik}

Pendidikan karakter yang menyeluruh di SMP Muahmmadiyah Boarding School sudah mencankup semua nilai-nilai karakter kewarganegaraan. Namun dalam proses pembentukan karakternya tidak dapat dilakukan dengan cepat. Pada prosesnya membutuhkan waktu yang panjang seperti berinvestasi. MBS ini mempunyai moto yaitu membina imam, ilmu dan akhlak. Menurut risalah rosul dalam pendidikan muhammadiyah adalah keimanan kemudian dengan keimanan ya tentu harus sejajar dengan ilmu, dengan ilmu akan mencakup berbagai aspek ilmu kemasyarakatan, ilmu sosial dan ilmu yang sesuai dengan kebutuhan duniawai dan jumrowi.

MBS sebagai salah satu lembaga pembinaan akhlak dan pencetak kader pemimpin bangsa dibutuhkan kerja keras dari berbagai elemen di sekolah dan asrama. Hal tersebut dilakukan melalui pertemuan seminggu sekali yang dihadiri guru, pegawai TU, pegawai koperasi, pegawai dapur, toko besi semua kumpulkan jadi satu. Pertemuan tersebut membahas persamaan persepsi tentang visi dan misi MBS. Ditanamkan pemikiran bahwa bekerja tidak hanya uang yang dicari, namun lebih dari itu menyiapkan generasi 
muda yang berkarakter.

Karakter kewarganegaraan yang terdiri dari mandiri, tanggung jawab, menghormati hak individu, demokrasi, dan berpartisipasi dilakukan melalui berbagai pendekatan. Menciptakan kerakter tersebut bukanlah hal yang mudah harus ada upaya pembiasaan, keteladan dan adanya penghargaan dan sanksi. Strateginya yaitu keteladan dari ustaz/ustadznya, pembiasaan langsung melalu kegiatan dan program-program MBS, pemberian nasihat serta sanksi. Pembiasan karakter secara langsung menjadi pembeda MBS dengan sekolah laninnya. Contoh keteladanan semua ustaz/ustadz memberikan teladan dalam bentuk tindakan baik untuk shalat berjamaah bersama, mengajar tepat waktu, ustad tidak merokok, dan lain sebagainya.

Pertama, pendidikan karakter dilakukan selama 24 jam melalui pembiasaan kegiatan yang ada di sekolah dan pondok yang memuat nilai-nilai karakter. Harapnya karakter tersebut dapat tertanam dan tidak luntur. Kedua adalah dengan cara keteladanan dari gurunya, jadi peserta didik membutuhkan seorang figur yang berkarakter. Ketiga, pembiasaan karakter melalui berbagai kegiatan dilakukan secara berkesinambungan dan terus menerus, serta perlunya pengawasan, pemantauan dan evaluasi.

Pembiasaan untuk membangun karakter mandiri yaitu dengan mematuhi segala peraturan yang dibuat di MBS, mengelola waktu secara efektif antara waktu sekolah (KBM), kegiatan asrama, dan ekstrakurikuler, pembiasaan mencuci pakai sendiri, pembiasaan memecahkan masalah sendiri, membiasakan dan merapihkan kamar sendiri. Ikatan Pelajar Muhammadiyah (IPM) adalah salah satu organisasi yang membuktikan karakter kemandirian para peserta didik. IPM berperan mengatur para adik-adik kelas dalam mematuhi atauran MBS.

Pembiasaan membangun karakter tanggung jawab yaitu dengan membiasaan peserta didik untuk mengurus dirinya sendiri, bertanggung jawab atas perilakunya sendiri dan siap menerima sanksi apabila melakukan pelanggaran. Peserta didik harus disiplin dalam segala kegiatan mulai dari bangun shalat tahajud, shalat fardu berjamaah, puasa senin-kamis, belajar di sekolah, hingga tidur kembali.

Pembiasaan membangun karakter menghormati harkat dan martabat orang lain. Di SMP MBS Yogyakarta peserta didik terdiri dari berbagai suku dari berbagai wilayah, bahkan ada yang dari luar negeri yaitu Malaysia dan Thailand. Melalui pembiasaan berkomunikasi dengan sistem pondok yaitu 24 jam, maka mereka saling bertukar informasi mulai dari kebudayaan dan kebiasaan dalam koridor sistem yang ada di MBS. Kegiatan 3S (senyum, sapa, salam) merupakan pembiasaan yang dilakukan guna menumbuh kembangkan rasa hormat dan menghargai satu sama lain baik peserta didik kepada gurunya maupun kepada peserta didik lainnya.

Pembiasaan membangun karakter berpartisipasi, MBS membiasakan menumbuh kembangkan rasa memiliki terhadap lembaga itu sendiri. Rasa memiliki diwujdukan dengan cara mereka harus berpartisipasi dengan segala program yang dibuat oleh MBS. Contoh ketika diadakan budaya cinta kebersihan, peserta didik harus mengikuti kerja bakti setiap hari Jumat pagi pukul 08.00 WIB untuk membersihkan lingkungan pondok. Kemudian partisipasi dalam melaksanakan kegiatan kurban mulai dari mengkuliti hingga membagikan hewan kurban kepada masyarakat sekitar.

Pembiasaan membanggun karakter demokrasi melalui penyampaian aspirasi peserta didik yang diwakilkan IPM. Kemudian setiap satu tahun sekali diadakan pemilu dalam rangka pemilihan ketua IPM. Demokrasi di dalam kelas diwujudkan melalui pemilihan pengurus jelas dengan sistem musyawarah mufakat. Adapun kontrak belajar yang dilakukan menggunakan kesepakatan antara guru dan peserta didiknya.

Tujuan dari pembiasaan karakter yang baik pada peserta didik di SMP MBS Yogyakarta nantinya mempersiapkan mereka menjadi warga negara yang baik memiliki tanggung jawab 
sosial, menghormati hak asasi manusia, taat kepada hukum, memiliki semangat kebangsaan, berkarakter demokrasi dan lain sebagainya.

Untuk dapat membangun karakter anak maka diperlukan sanksi yang bersifat membangun. Dari hasil wawancara dengan beberapa narasumber dapat diketahui bahwa pada lingkungan SMP Muhammadiyah Boarding School Yogyakarta pedoman pelaksanaan pemberian sanksi terhadap santri yang melanggar peraturan tata tertib telah ditentukan dalam sebuah buku tata tertib santri, sehingga pelaksanaanya sesuai dengan aturan yang ada. Menurut buku panduan santri bentuk sanksi yang diberikan berdasarkan tahapan atau alternatif sanksi yaitu ada 3 jenis klasifikasi (1) point 1-75 dihukum untuk mencari mufradat, menghafal dan merangkum, presensi ke pembina, menyapu, mengepel, meminta nasehat, membersihkan lingkugan pondok, (2) point 75100 dihukum untuk membuat dan membaca surat pernyataan, menghafal mufradat, membersikan wc, mencuci pakai baksos dan lain-lain, (3) point 100-150 dihukum dengan memanggil orang tua, mendapat surat peringatan, skorsing, dikembalikan ke orang tua wali, memakai jilbab khusus untuk santriwati, gundul untuk santri dan lain-lain. Hal ini dimaksudkan agar peserta didik jera dan tidak mengulangi lagi kesalahannya.

\section{Faktor Pendukung Dalam Upaya Pembiasaan Karakter Kewarganegaraan}

Pembiasaan karakter peserta didik dipengaruhi oleh berbagai faktor baik internal maupun eksternal. Faktor pendukung pembiasaan karakter kewarganegaraan di SMP Muhammadiyah Boarding School Yogyakarta terdiri atas faktor internal dan ekternal. Faktor internal yaitu: (1) peraturan tata tertib dan kultur sekolah, (2) dukungan dan kerja sama yang baik antar seluruh warga sekolah (pimpinan, guru, peserta didik, petugas keamanan, petugas kebersihan dll), dan (3) dukungan orang tua peserta didik. Faktor eksternalnya yaitu kerjasama pihak sekolah dengan masyarakat.

Dari hasil penelitian kelebihan dari boarding school adalah pembinaan selama 24 jam, sehingga dalam proses pembiasaan karakter kewarganegaraan dapat berjalan secara optimal. Begitu pula di SMP Muhammadiyah Boarding School Yogyakarta mulai dari kegiatan untuk para peserta didik mencerminkan dan mengandung nilai-nilai karakter yang baik. Hal ini sesuai dengan pendapat Ab A'ala (2006, p.49) bahwa berdirinya boarding school sangat menekankan kepada moralitas, menjunjung tinggi kemandirian, kesederhanaa dan sejenisnnya.

\section{Faktor Penghambat Dalam Upaya Pembiasaan Karakter Kewarganegaraan}

Dalam setiap pembiasaan sebuah karakter ada selain ada faktor pendukung ada pula faktor penghambatnya. Pelaksanaan pembiasaan karakter kewarganegraan di SMP Muhammadiyah Boarding School Yogyakarta tentunya tidak lepas dari kendala atau hambatanhambatan yang terjadi, baik hambatan yang muncul dari dalam maupun luar. Terdapat beberapa hambatan dalam pembiasaan karakter peserta didik yaitu pertama, kurangnya sarana dan prasarana dalam KBM guna pencapain kompeensi dasar dan penanaman nilai. Kedua, kurangnya SDM maksudnya adalah pembina asrama yang mau tinggal selama 24 jam setiap hari mendampingi para santri. Ketiga, perbedaan latar belakang keluarga para santri (perbedaan tingkat ekonomi, bahasa dan kebiasaan).

Pengelolaan sarana dan prasarana dalam satuan pendidikan harus dilaksanakan. Mulyasana (2014: 72) mengungkapkan bahwa pengelolaan saraan sudah sewajarnya dilakukan oleh satuan pendidikan sekolah tidak terkecuali lembaga pondok pesantren. Mulai dari pengadaan, pemeliharaan, perbaikan dan pengembangannya. SMP Muhammadiyah Boarding School Yogyakarta memiliki sarana dan prasana kurang lengkap yaitu ruang TIK, ruang laboratorium, pepustakaan dan lapangan olahraga yang belum representative. Sarana prasana dan sumber belajar yang memadai selain membantu kelancaran implementasi pendidikan karakter, juga membantu mempercepat sosialisasi pendidikan karakter kepada seluruh warga sekolah dan masyarakat lingkungannya.

Keterbatasan dana juga menjadi salah satu factor penghambat. Selama ini dana yang diperlukan untuk pengembangam sarana dan prasarana seperti pengadaan laboratorium, pengadaan komputer masih mengandalkan dana dari orang tua peserta didik. Minimnya dana operasional secara tidak langsung berakibat pada keterlaksanaan program pendidikan karakter 
tidak optimal, demikian pula kelancaran proses penyelenggaraan pendidikan di sekolah juga terhambat.

Perbedaan latarbelakang keluarga (perbedaan tingkat ekonomi, bahasa dan kebiasaan) menjadi salah satu faktor yang menghambat dalam pembiasaan karakter di lingkungan SMP MBS Yogyakarta. Sebagai contoh, ada santri yang hanya dengan suruhan kata-kata mudah memahami dan melaksanakan suatu kebiasaan yang positif yang ada di lingkungan SMP MBS Yogyakarta, ada pula yang sangat sulit untuk melaksankan hal tersebut. Santri seperti ini akan mengikuti perintah apabila telah diberikan sanksi tertentu. Sifat santri seperti ini merupakan salah satu hal yang disebabkan adanya perbedaan latar balakang santri.

\section{SIMPULAN DAN SARAN}

\section{Simpulan}

Berdasarkan hasil penelitian dan pembahasan yang dilakukan, dapat ditarik kesimpulan sebagai berikut.

Proses pembiasaan karakter di SMP Muhammadiyah Boarding School Yogyakarta dilakukan secara holistic melalui proses pengintegrasian baik dalam KBM, kultur sekolah, ekstrakulikuler dan kegiatan bermasyarakat. Segala program untuk peserta didik baik harian, mingguan, bulanan dan tahunan mengandung nilai-nilai karakter kewarganegaraan yang ingin diterapkan.

Strategi yang digunakan guna pembiasaan karakter kewarganegaraan dilakukan melalui pemberian nasihat, pembiasaan akhlak yang baik, pemberian penghargaan dan sanksi (reward and punishment), dan keteladanan guru (ustaz/ustazah).

Faktor pendukung dalam pembiasaan karakter kewarganegaraan terdiri atas faktor internal dan eksternal. Faktor internal berupa peraturan tata tertib dan kultur sekolah, dukungan dan kerja sama yang baik antar seluru warga sekolah, dan dukungan dari orang tua peserta didik. Faktor eksternalnya berupa dukungan dan kerja sama pihak sekolah dan masyarakat. Adapun faktor penghambatnya yaitu minimnya sarana dan prasarana, proporsi yang tidak seimbang antara pembina asrama dan jumlah santri, dana atau pembiayaan, serta karakter santri dengan latar belakang keluarga yang berbeda.

\section{Saran}

Dari pemabahasan dan kesimpulan maka dapat di rumuskan beberapa saran misalnya seharusnya pemerintah hendaknya memfasilitasi sekolah-sekolah yang memberikan warna baru dalam dunia pendidikan yang mengedepankan nilai moral melalui pemberian fasilitas berupa materiil ataupun pelatihan-pelatihan agar dapat lebih mengembangkan kreativitas guru dalam pengembangan karakter.

Melihat kendala-kendala yang terjadi dalam proses pembiasaan karakter, maka perlu diidentifikasi masalah yang ada dan selanjutnya mencari solusi serta ditindaklanjuti. Kemudian penggunaan bahasa Indonesia bisa dijadikan sebagai bahasa wajib baik ketika KBM maupun kegiatan dalam pondok pesantren agar dapat menumbuhkan rasa nasionalisme pada siswa.

\section{DAFTAR PUSTAKA}

Abd A'la.(2006). Pembaruan pesantren. Yogyakarta: Pustaka Pesantren.

Abdul Majid. (2011). Pendidikan karakter persepektif

Islam. Bandung: Remaja Rosdakarya.

Akhmad Muhaimin Azzet. (2011). Urgensi pendidikan karakter di Indonesia. Yogyakarta: Ar-Ruzz Media.

Cogan, J.J. (1991). Developing the civic society: the role of civic education. Bandung: CICED.

Creswell, J. (2013). Research design qualitative, quantitative, and mixed Approaches. California: Sage Publications.

Darmiyati Zuchdi, dkk. (2006). Pemetaan implementasi pendidikan karakter di SD, SM, dan SMA di Kota Yogyakarta. Laporan Penelitian Hibah Pascasarjana Universitas Negeri Yogyakrta.

Doni Purnomo. (25 Januari 2012). Pengertian pendidikan karakter. Diambil pada 15 Oktober 2015 pada pukul 21.00 WIB dari http://dony.blog.uns.ac.id/2012/01/25/pe ngertian-pendidikan-karakter/. 
Citizenship Jurnal Pancasila dan Kewarganegaraan Vol 6 No 1 April 2018, hal 52-62

Avaliable online at : http://e-journal.unipma.ac.id/index.php/Citizenship

Print ISSN: 2302-433X Online ISSN : 2579-5740

Kardiman, Y. (2008). Membangun kembali karakter bangsa melalui situs-situs kewarganegaraan. Bandung: Jurnal Pendidikan Kewarganegaraan. Acta Civicus. Vol. 2. No. 2.

Kementrian Pendidikan Nasional. (2010). Pengembangan pendidikan budaya dan karakter bangsa. Jakarta: Kementrian Pendidikan Nasional.

Lickona, Thomas. (1991). Educating for character:

how our school can teach respect and responsibility. New York, Toronto, London, Sydney, Aucland: Bantam Books.

(2013). Pendidikan karakter panduan lengkap mendidik peserta didik menjadi pintar dan baik. Bandung: Penerbit Nusa Media.

Maksudin. (2013). Pendidikan Islam alternatif: membangun karakter melalui sistem boarding school. Yogyakarta: UNY Press.

.(2013). Pendidikan karakter nondikotomik (upaya membangun bangsa Indonesia seutuhnya). Jurnal pendidikan karakter Lembaga Pengembangan dan Penjaminan Mutu Pendidikan (LPPMP) Universitas Negeri Yogyakarta. Yogyakarta: Lembaga Pengembangan dan Penjaminan Mutu Pendidikan.
Marzuki, M., \& Feriandi, Y. A. Pengaruh Peran Guru Ppkn dan Pola Asuh Orang Tua terhadap Tindakan Moral Siswa. Jurnal Kependidikan: Penelitian Inovasi Pembelajaran, 46(2), 193-206.

Masnur Muslich. (2011). Pendidikan karakter: menjawab tantangan krisis multidemensional. Jakarta: Bumi Aksara.

Ratna Megawangi. (2004). Pendidikan karakter solusi yang tepat untuk membangun bangsa. Bogor: Indonesia Heritage Foundation.

. (2007). Semua berakar pada pendidikan karakter. Jakarta: Lembaga penerbit Fakultas Ekonomi UI.

Rita Eka Izzaty, dkk. (2008). Pengembangan peserta didik.Yogyakarta: UNY Press.

Sugiyono, (2013). Metode penelitian pendidikan, pendekatan kuantitatif, kualitatif dan $R \& D$. Bandung: Alfabeta. 